\title{
Meta-Analysis of Mitochondrial DNA Reveals Several Population Bottlenecks during Worldwide Migrations of Cattle
}

Johannes A. Lenstra ${ }^{1, *}$, Paolo Ajmone-Marsan ${ }^{2}$, Albano Beja-Pereira ${ }^{3}$, Ruth Bollongino ${ }^{4}$, Daniel G. Bradley ${ }^{5}$, Licia Colli ${ }^{2}$, Anna De Gaetano ${ }^{6}$, Ceiridwen J. Edwards ${ }^{5,7}$, Marleen Felius ${ }^{8}$, Luca Ferretti ${ }^{6}$, Catarina Ginja ${ }^{9}$, Peter Hristov ${ }^{10}$, Juha Kantanen ${ }^{11}$, Juan Pedro Lirón ${ }^{12}$, David A. Magee ${ }^{5,13}$, Riccardo Negrini ${ }^{2}$ and Georgi A. Radoslavov ${ }^{10}$

1 Faculty of Veterinary Medicine, Utrecht University, Yalelaan 104, Utrecht 3584CM, The Netherlands

2 Università Cattolica del Sacro Cuore, Institute of Zootechnics and BioDNA-Biodiversity and Ancient DNA Research Center, Via Emilia Parmense 84, Piacenza 29122, Italy; E-Mails: paolo.ajmone@unicatt.it (P.A.-M.); licia.colli@unicatt.it (L.C.); riccardo.negrini@unicatt.it (R.N.) Centro de Investigação em Biodiversidade e Recursos Genéticos da Universidade do Porto (CIBIO/UP), Campus Agrário de Vairão, Rua Padre Armando Quintas 7, Vairão 4485-661, Portugal;

E-Mail: albanobp@fc.up.pt

4 Institute of Anthropology, Johannes-Gutenberg University Mainz, Anselm-Franz-von-Bentzel-Weg 7, Mainz 55128, Germany; E-Mail: bollongi@uni-mainz.de

5 Smurfit Institute of Genetics, Trinity College, Dublin 2, Ireland; E-Mail: dbradley@tcd.ie

6 Dipartimento di Biologia e Biotecnologie “L. Spallanzani”, Università di Pavia, Pavia 27100, Italy; E-Mail: anna.degaetano@unipv.it (A.D.G.); luca.ferretti@unipv.it (L.F.)

7 Research Laboratory for Archaeology, University of Oxford, Dyson Perrins Building, South Parks Road, Oxford OX1 3QY, UK; E-Mail: ceiridwen.edwards@rlaha.ox.ac.uk

8 Mauritsstraat 167, Rotterdam 3012 CH, The Netherlands; E-Mail: info@marleenfelius.eu

9 Centro de Biologia Ambiental, Faculdade de Ciências, Universidade de Lisboa, Lisboa 1749-016, Portugal; E-Mail: catarinaginja@gmail.com

10 Bulgarian Academy of Sciences, Institute of Biodiversity and Ecosystem Research, “Acad. Georgi Bonchev” str., bl. 25, Sofia 1113, Bulgaria; E-Mails: peter_hristoff@abv.bg (P.H.); gradoslavov@gmail.com (G.A.R.)

11 Biotechnology and Food Research, MTT Agrifood Research Finland, Jokioinen, Finland and Department of Biology, University of Eastern Finland, P.O. Box 1627, FI-70211 Kuopio, Finland; E-Mail: juha.kantanen@mtt.fi

12 CIGEBA, Facultad de Ciencias Veterinarias, Universidad Nacional de La Plata, Calle 60 y 118 s/n, La Plata, Buenos Aires 1900, Argentina; E-Mail: juanpedroliron@gmail.com

13 Animal Genomics Laboratory, UCD School of Agriculture and Food Science, University College Dublin, Belfield, Dublin 4, Ireland; E-Mail: david.magee@ucd.ie 
* Author to whom correspondence should be addressed; E-Mail: J.A.Lenstra@uu.nl;

Tel.: +31-30-253-4992; Fax: +31-31-253-5077.

Received: 13 January 2014; in revised form: 26 February 2014 / Accepted: 28 February 2014 /

Published: 14 March 2014

\begin{abstract}
Several studies have investigated the differentiation of mitochondrial DNA in Eurasian, African and American cattle as well as archaeological bovine material. A global survey of these studies shows that haplogroup distributions are more stable in time than in space. All major migrations of cattle have shifted the haplogroup distributions considerably with a reduction of the number of haplogroups and/or an expansion of haplotypes that are rare or absent in the ancestral populations. The most extreme case is the almost exclusive colonization of Africa by the $\mathrm{T} 1$ haplogroup, which is rare in Southwest Asian cattle. In contrast, ancient samples invariably show continuity with present-day cattle from the same location. These findings indicate strong maternal founder effects followed by limited maternal gene flow when new territories are colonized. However, effects of adaptation to new environments may also play a role.
\end{abstract}

Keywords: cattle; breeds; mitochondrial DNA; haplogroups; migrations

\title{
1. Introduction
}

During the past decades, analysis of mitochondrial DNA (mtDNA) has become the backbone of molecular-genetic investigations of animal population diversity and history [1]. Due to its high variability, informative datasets can be collected relatively fast, while its high copy number increases the chance of retrieving DNA from archaeological material. In addition, the interpretation of mtDNA datasets is facilitated by maternal transmission and absence of recombination; the latter generating a straightforward hierarchical clustering [2].

For several livestock species, mtDNA analyses established the ancestral species and contributed to evidence for the localization of domestication sites [3]. The finding of two separate domestication events, one for taurine (Bos taurus) and one for zebu (Bos indicus) cattle [4,5], corresponded with the archaeological record. The exclusive presence of taurine mtDNA in African zebu [4] indicated that zebu was introduced into Africa by male introgression alone and demonstrated the unique contribution of mtDNA analysis to the reconstruction of agricultural history. Since then, numerous studies have explored the mitochondrial diversity of cattle populations worldwide (Table S1). Five taurine (T) and two indicine (I) haplogroups account for the vast majority of mtDNA haplotypes [6-9]. Complete mtDNA sequences have established an accurate phylogeny and indicated a Southwest-Asian origin for all major $\mathrm{T}$ haplogroups, including the African T1 and East-Asian T4 [10,11]. These and other studies also identified the rare haplogroups P, Q and R, with P and R most likely derived from European aurochs [12-14].

Focusing on the major haplogroups, we combined the results of several regional studies of the cattle mtDNA control region (Table S1). This global meta-analysis allows a few generalizations about shifts 
in haplogroup distributions, suggesting strong founder effects during colonization of Europe, East Asia, Africa and America, but little temporal variation.

\section{Experimental Section}

Table S1 shows the sources of cattle mtDNA datasets used in this study with a total of 6695 D-loop sequences. The haplogroups T, T1, T2, T3 and T4 could be differentiated by variation within a 240-bp D-loop segment [6,8,9,12]. In this study haplogroup T denotes the combination of T, T1'2'3 and T5. Haplogroup counts were taken directly from publications or based on haplotype scoring of reported GenBank entries.

\section{Results and Discussion}

A worldwide geographic plot of haplogroup distributions (Figure 1) visualizes several spatial contrasts. Troy et al. [6] already noted the high haplogroup diversity in Southwest Asia with four major haplogroups T, T1, T2 and T3, the dominance of haplogroup T3 in Europe and the almost exclusive occurrence of T1 in Africa. A recent analysis of Neolithic samples from Iran revealed the same haplogroup diversity as observed in present Southwest Asian cattle [15], while T3 was already predominant in Central and Northwestern Europe during the Neolithic [16-23] (Figure 2). The combination of data from several sources now suggests that the entry of cattle into Europe ca. 8,500 BP largely reduced the frequency of haplogroups $\mathrm{T}$ and $\mathrm{T} 1$. Haplogroup $\mathrm{T} 2$ still has appreciable frequencies in Italian, Balkan and Asian taurine cattle, but is found only sporadically in Central, Western and Northern Europe.

The presence of $\mathrm{T} 1$ in the Iberian peninsula suggests prehistoric and/or later African influence [19,24,25]. This is also the most likely explanation for a similar frequency of T1 in the Podolian breeds from Sicily and South Italy. The maternal lineages in Central-Italian large white and Podolian cattle (Chianina, Maremmana, Romagnola, Marchigiana), with frequencies for both $\mathrm{T} 1$ and $\mathrm{T} 2$ of around 10\%, are intermediate between those of the South-Italian and Balkan Podolian cattle. Thus, a proposed Anatolian origin of maternal lineages from Tuscany by immigration of cattle well after the Neolithic colonization of Italy [26] can be extended to neighboring Podolian breeds. A genetic link between mtDNA from Anatolian and Italian cattle, implying transport of cows, may have been mediated by the Tuscans [26] and/or correspond to the documented import since the 8th century BC of large cattle from Epirus (present South Albania-Northwest Greece) to Italy [27]. In Africa, haplotypes from haplogroups other than T1 have been found only in Egypt (combined frequency 38.5\%) and Northwest Africa (less than 2\%) and are completely absent in the rest of the continent. A recent comprehensive study of whole mtDNA of the T1 haplogroup identified eight haplotypes as founders of the African T1 population [11]. Estimates of coalescence times for the T1 sub-haplogroups (6,200 to 12,900 BP) and their current geographic distributions are compatible with a Southwest-Asian origin for most T1 sub-haplogroups, which for sub-haplogroup T1c1 has been confirmed by it discovery in Iraq [14]. It is not clear yet how to explain the overrepresentation in Africa of different sub-haplogroups exclusively from the T1 haplogroup. Possible explanations include positive selection of T1 mtDNA (see below), inherent uncertainties in time estimates and overestimations of the divergence times for recent taxa [28,29]. Shorter divergence times would allow an alternative scenario of a small herd with a high frequency of T1 reaching Africa, expanding and only then splitting into the different T1 sub-haplogroups. 
Figure 1. Distributions of major taurine and indicine haplogroups. T1* indicates T1c1a1 [11], previously denoted as AA [8].

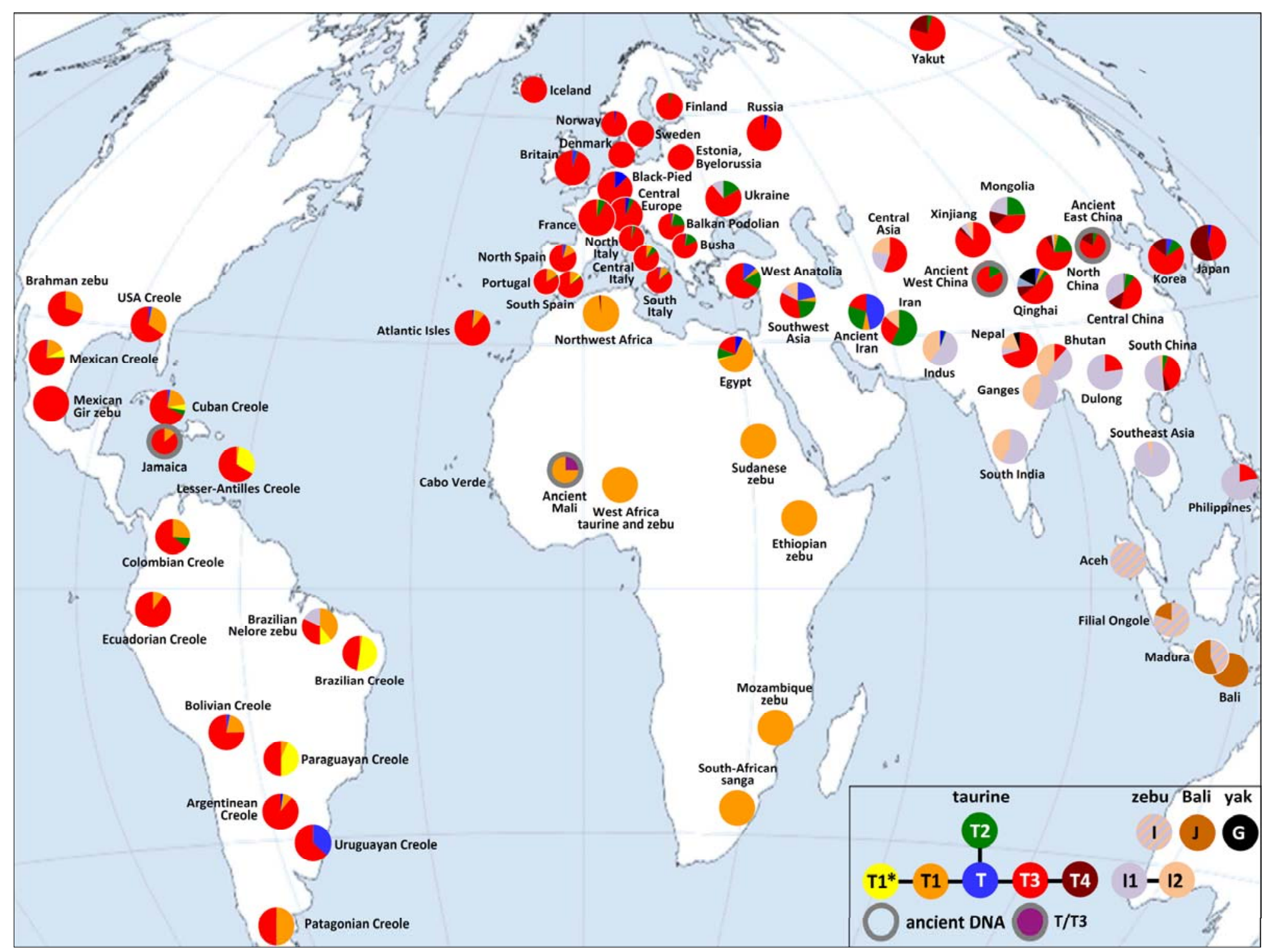


Figure 2. Mitochondrial DNA (MtDNA) haplogroup distributions in European and Southwest-Asian ancient DNA samples from domestic cattle. Data are from [16-23].

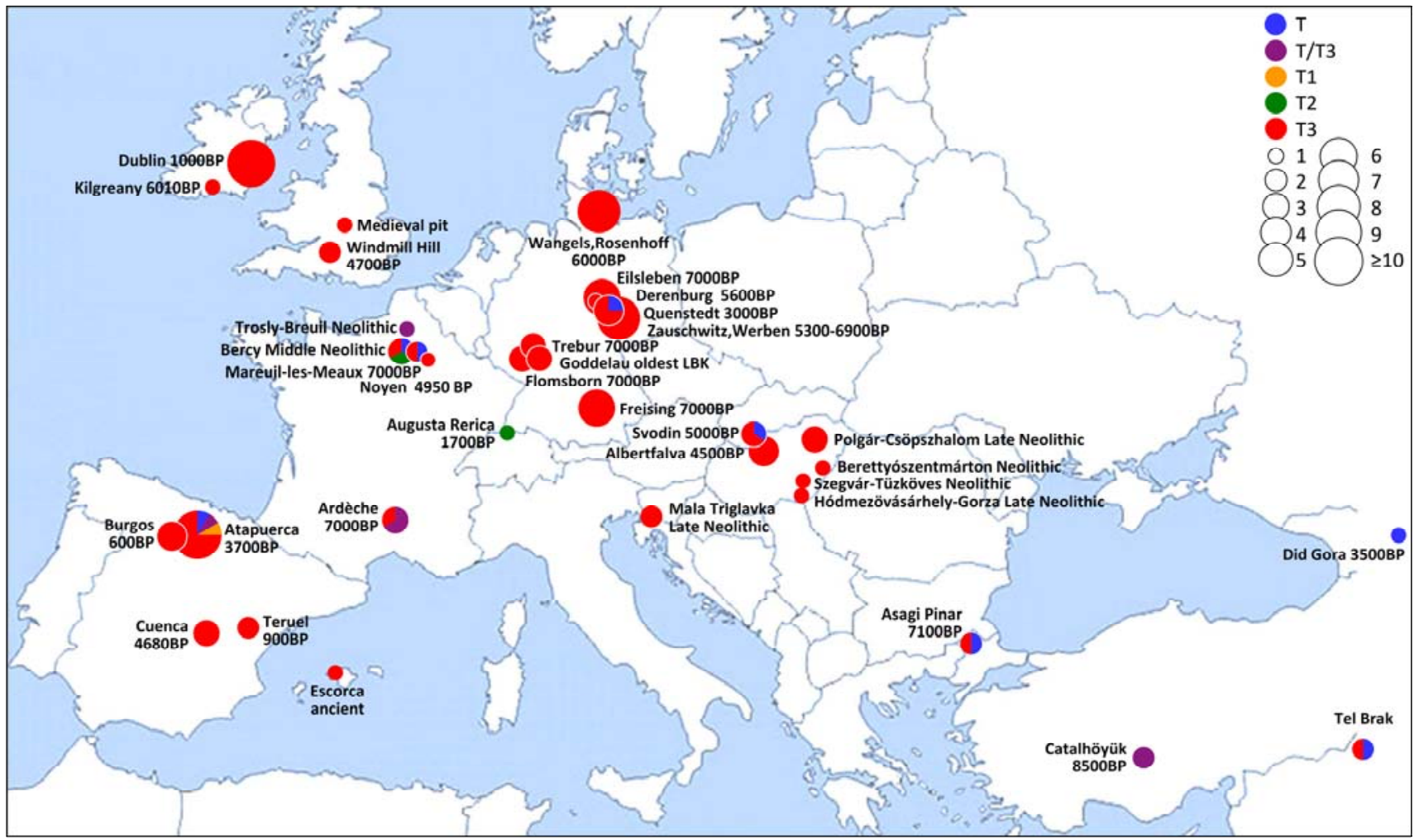

Migration from Central to East Asia led to the expansion of haplogroup T4. This is a subvariant of T3, which is not observed in the west, but has been found in East-Chinese ancient DNA dating to 4500 BP [30], in modern Korean beef cattle [10] and in more than half of the Japanese cattle [31]. It is also at a frequency of $21 \%$ in the North-Siberian Yakut [32], indicating a link between the Yakut and cattle from East-China.

A similar expansion occurred during the colonization of the New World since the end of the 15th century. Haplogroup distributions, with T3 as major and T1 as minor, reflect the Iberian ancestry of American cattle. Although the T1 haplotype T1c1a1 is sporadic in the Old World it reaches frequencies of $31 \%$ in the Caribbean Lesser Antilles islands and even 50\% in Brazilian Criollo cattle $[8,14,33]$. Portuguese colonists imported the first cattle to Brazil in 1534 from Cabo Verde near the West-African coast [34], while the English and French colonists settled only in the 17th century in the Lesser Antilles. This suggests a scenario in which cattle carrying the T1c1a1 haplotype originated either from Portugal or Africa, grew in number on Cabo Verde or in Brazil and were later exported to the nearby Caribbean isles.

Indicine maternal lineages from haplogroups I1 and I2 diffused from South Asia to Southwest and Central Asia [9,35]. Haplogroups I1 predominated in the cattle that moved eastwards to Southeast Asia and China. Populations with a mixed taurine and indicine maternal origin are found in Southwest Asia, the Indus Valley, Central Asia, Nepal, Bhutan, China, Mongolian and Brazil. The gayal population from Yunnan in South China combines I1 and T3 mtDNA with paternal lineages from the gayal (Bos frontalis) or wild gaur (Bos gaurus) [36]. In Indonesia, zebu introgressed into local populations of domestic 
banteng (Bos javanicus), which have partially retained their original javacine origin in their mtDNA [37]. Maternal yak (Bos grunniens) introgression has been observed in Nepal [38] and Qinghai [39].

Geographic differentiation of cattle mtDNA is clearly stronger than observed for sheep, goat and horse, which exhibits a broader distribution of the major mtDNA haplogroups [1]. Sequencing of ancient mtDNA from remains of domestic cattle found in Europe, Iran, China and the Caribbean invariably shows continuity with present-day animals from the same region. This suggests that abrupt shifts in haplotype frequencies were caused by strong founder effects during the earliest migrations of cattle, which apparently involved only a few individuals. It is plausible that it was easier to transport larger groups of the smaller and more manageable goats and sheep, while mobility of horses was promoted by trading and wars. The strong geographic differentiation of mtDNA in the Chinese population of swamp type of water buffalo [40] supports the hypothesis that differentiation of maternal lineages correlates with a low mobility of the herds.

Selection offers an alternative explanation for the strong phylogeography seen in bovine mtDNA. Purifying selection acting on mtDNA has been demonstrated for both bovine and other mammals [41], although it may be weaker for domestic livestock than for wild species [42]. Positive selection may improve the adaptation of cattle to different environments. One of the T4-specific substitutions leads to an L380M mutation in the cytochrome $b$ gene and the G1324A substitution in T1c1a1 causes a mutated rRNA. However, no differences have been found in production and reproduction traits between Brazilian Guzerat zebus carrying taurine mtDNA and those carrying indicine mtDNA [43]. Nonetheless, there is no a priori reason why mtDNA-encoded gene products cannot be involved in selection and contribute to traits relevant for adaptation or production, thus leading to geographic differentiation of mtDNA.

\section{Conclusions}

We conclude that the meta-analysis of bovine mtDNA sequences from both present and archaeological samples allows for a global picture of geographic differentiation of the maternal lineages, which have been shaped by population bottlenecks during the worldwide dispersal of cattle. As shown for haplogroup T1 in Africa [11,44], whole-mtDNA sequencing may detect additional sub-haplogroups informative for movements of cattle between or within continents and expansion of populations. Ancient DNA studies contribute essentially to the historic reconstructions by providing geographic and historic anchor points for specific haplotypes.

\section{Supplementary Materials}

Supplementary materials can be accessed at: http://www.mdpi.com/1424-2818/6/1/178/s1.

\section{Acknowledgements}

We acknowledge several published or unpublished contributions to the mitochondrial DNA sequence dataset described in this report. We appreciate the suggestions of both reviewers. 


\section{Author Contributions}

Johannes A. Lenstra initiated this study and wrote the first draft. Paolo Ajmone-Marsan, Albano Beja-Pereira, Ruth Bollongino, Daniel G. Bradley, Licia Colli, Anna De Gaetano, Ceiridwen J. Edwards, Luca Ferretti, Catarina Ginja, Peter Hristov, Juha Kantanen, Juan Pedro Lirón, David A. Magee, Riccardo Negrini and Georgi A. Radoslavov contributed to data compilation, Paolo Ajmone-Marsan, Luca Ferretti and Marleen Felius to the historic interpretation and Ceiridwen J. Edwards to final editing.

\section{Conflicts of interest}

The authors declare no conflict of interest

\section{References}

1. Groeneveld, L.F.; Lenstra, J.A.; Eding, H.; Toro, M.A.; Scherf, B.; Pilling, D.; Negrini, R.; Finlay, E.K.; Jianlin, H.; Groeneveld, E.; et al. Genetic diversity in farm animals: A review. Anim. Genet. 2010, 41, 6-31.

2. Lenstra, J.A.; Groeneveld, L.F.; Eding, H.; Kantanen, J.; Williams, J.L.; Taberlet, P.; Nicolazzi, E.L.; Sölkner, J.; Simianer, H.; Ciani, E.; et al. Molecular tools and analytical approaches for the characterization of farm animal diversity. Anim. Genet. 2012, 43, 483-502.

3. Zeder, M.A.; Emshwiller, E.; Smith, B.D.; Bradley, D.G. Documenting domestication: The intersection of genetics and archaeology. Trends Genet. 2006, 22, 139-155.

4. Bradley, D.G.; Loftus, R.T.; Cunningham, C.; MacHugh, D.E. Genetics and domestic cattle origin. Evol. Anthropol. 1998, 6, 79-86.

5. Ajmone-Marsan, P.; Garcia, J.F.; Lenstra, J.A. On the origin of cattle: How aurochs became cattle and colonized the world. Evol. Anthropol. 2010, 19, 148-157.

6. Troy, C.S.; MacHugh, D.E.; Bailey, J.F.; Magee, D.A.; Loftus, R.T.; Cunningham, P.; Chamberlain, A.T.; Sykes, B.C.; Bradley, D.G. Genetic evidence for Near-Eastern origins of European cattle. Nature 2001, 410, 1088-1091.

7. Mannen, H.; Kohno, M.; Nagata, Y.; Tsuji, S.; Bradley, D.G.; Yeo, J.S.; Nyamsamba, D.; Zagdsuren, Y.; Yokohama, M.; Nomura, K.; et al. Independent mitochondrial origin and historical genetic differentiation in North Eastern Asian cattle. Molec. Phylogenet. Evol. 2004, 32, 539-544.

8. Ginja, C.; Penedo, M.C.; Melucci, L.; Quiroz, J.; Martinez Lopez, O.R.; Revidatti, M.A.; Martinez-Martinez, A.; Delgado, J.V.; Gama, L.T. Origins and genetic diversity of New World Creole cattle: Inferences from mitochondrial and Y chromosome polymorphisms. Anim. Genet. 2010, 41, 128-141.

9. Chen, S.; Lin, B.Z.; Baig, M.; Mitra, B.; Lopes, R.J.; Santos, A.M.; Magee, D.A.; Azevedo, M.; Tarroso, P.; Sasazaki, S.; et al. Zebu cattle are an exclusive legacy of the South Asia Neolithic. Molec. Biol. Evol. 2010, 27, 1-6.

10. Achilli, A.; Olivieri, A.; Pellecchia, M.; Uboldi, C.; Colli, L.; Al-Zahery, N.; Accetturo, M.; Pala, M.; Hooshiar Kashani, B.; Perego, U.A.; et al. Mitochondrial genomes of extinct aurochs survive in domestic cattle. Curr. Biol. 2008, 18, R157-R158. 
11. Bonfiglio, S.; Ginja, C.; de Gaetano, A.; Achilli, A.; Olivieri, A.; Colli, L.; Tesfaye, K.; Agha, S.H.; Gama, L.T.; Cattonaro, F.; et al. Origin and spread of Bos taurus: New clues from mitochondrial genomes belonging to haplogroup T1. PLoS One 2012, 7, e38601.

12. Achilli, A.; Bonfiglio, S.; Olivieri, A.; Malusa, A.; Pala, M.; Hooshiar Kashani, B.; Perego, U.A.; Ajmone-Marsan, P.; Liotta, L.; Semino, O.; et al. The multifaceted origin of taurine cattle reflected by the mitochondrial genome. PLoS One 2009, 4, e5753.

13. Stock, F.; Edwards, C.J.; Bollongino, R.; Finlay, E.K.; Burger, J.; Bradley, D.G. Cytochrome $b$ sequences of ancient cattle and wild ox support phylogenetic complexity in the ancient and modern bovine populations. Anim. Genet. 2009, 40, 694-700.

14. Bonfiglio, S.; Achilli, A.; Olivieri, A.; Negrini, R.; Colli, L.; Liotta, L.; Ajmone-Marsan, P.; Torroni, A.; Ferretti, L. The enigmatic origin of bovine mtDNA haplogroup R: Sporadic interbreeding or an independent event of Bos primigenius domestication in Italy? PLoS One 2010, 5, e15760.

15. Bollongino, R.; Burger, J.; Powell, A.; Mashkour, M.; Vigne, J.D.; Thomas, M.G. Modern taurine cattle descended from small number of Near-Eastern founders. Molec. Biol. Evol. 2012, 29, 2101-2104.

16. Bailey, J.F.; Richards, M.B.; Macaulay, V.A.; Colson, I.B.; James, I.T.; Bradley, D.G.; Hedges, R.E.; Sykes, B.C. Ancient DNA suggests a recent expansion of European cattle from a diverse wild progenitor species. Proc. Royal Soc. B: Biol. Sci. 1996, 263, 1467-1473.

17. MacHugh, D.E.; Troy, C.S.; McCormick, F.; Olsaker, I.; Eythorsdottir, E.; Bradley, D.G. Early medieval cattle remains from a Scandinavian settlement in Dublin: Genetic analysis and comparison with extant breeds. Proc. Royal Soc. B: Biol. Sci. 1999, 354, 99-109.

18. Edwards, C.J.; MacHugh, D.E.; Dobney, K.M.; Martin, L.; Russell, N.; Horwitz, L.K.; McIntosh, S.K.; MacDonald, K.C.; Helmer, D.; Tresset, A.; et al. Ancient DNA analysis of 101 cattle remains: Limits and prospects. J. Archaeol. Sci. 2004, 31, 695-710.

19. Anderung, C.; Bouwman, A.; Persson, P.; Carretero, J.M.; Ortega, A.I.; Elburg, R.; Smith, C.; Arsuaga, J.L.; Ellegren, H.; Gotherstrom, A. Prehistoric contacts over the Straits of Gibraltar indicated by genetic analysis of Iberian Bronze Age cattle. Proc. Nat. Acad. Sci. USA 2005, 102, 8431-8435.

20. Kühn, R.; Ludt, C.; Manhart, H.; Peters, J.; Neumair, E.; Rottmann, O. Close genetic relationship of early Neolithic cattle from Ziegelberg (Freising, Germany) with modern breeds. J. Anim. Breeding Genet. 2005, 122, 36-44.

21. Bollongino, R.; Edwards, C.J.; Alt, K.W.; Burger, J.; Bradley, D.G. Early history of European domestic cattle as revealed by ancient DNA. Biol. Lett. 2006, 2, 155-159.

22. Edwards, C.J.; Bollongino, R.; Scheu, A.; Chamberlain, A.; Tresset, A.; Vigne, J.D.; Baird, J.F.; Larson, G.; Ho, S.Y.; Heupink, T.H.; et al. Mitochondrial DNA analysis shows a Near Eastern Neolithic origin for domestic cattle and no indication of domestication of European aurochs. Proc. Royal Soc. B: Biol. Sci. 2007, 274, 1377-1385.

23. Scheu, A.; Hartz, S.; Schmölcke, U.; Tresset, A.; Burger, J.; Bollongino, R. Ancient DNA provides no evidence for independent domestication of cattle in Mesolithic Rosenhof, Northern Germany. J. Archaeol. Sci. 2008, 35, 1257-1264. 
24. Cymbron, T.; Freeman, A.; Malheiro, M.I.; Vigne, J.D.; Bradley, D. Microsatellite diversity suggests different histories for Mediterranean and Northern European cattle populations. Proc. Royal Soc. B: Biol. Sci. 2005, 272, 1837-1843.

25. Beja-Pereira, A.; Caramelli, D.; Lalueza-Fox, C.; Vernesi, C.; Ferrand, N.; Casoli, A.; Goyache, F.; Royo, L.J.; Conti, S.; Lari, M.; et al. The origin of European cattle: Evidence from modern and ancient DNA. Proc. Nat. Acad. Sci. USA 2006, 103, 8113-8118.

26. Pellecchia, M.; Negrini, R.; Colli, L.; Patrini, M.; Milanesi, E.; Achilli, A.; Bertorelle, G.; Cavalli-Sforza, L.L.; Piazza, A.; Torroni, A.; et al. The mystery of Etruscan origins: Novel clues from Bos taurus mitochondrial DNA. Proc. Royal Soc. B: Biol. Sci. 2007, 274, 1175-1179.

27. Kron, H. Roman livestock farming in southern Italy: The case against environmental determinism. In Espaces Integrés et Ressources Naturelles dans l'Empire Romain; Clavel-Lévêque, M., Hermon, E., Eds.; Presses Universitaires de Franche-Comté: Besançon, France, 2004; pp. 119-134.

28. Ho, S.Y.; Larson, G.; Edwards, C.J.; Heupink, T.H.; Lakin, K.E.; Holland, P.W.; Shapiro, B. Correlating Bayesian date estimates with climatic events and domestication using a bovine case study. Biol. Lett. 2008, 4, 370-374.

29. Soubrier, J.; Steel, M.; Lee, M.S.; der Sarkissian, C.; Guindon, S.; Ho, S.Y.; Cooper, A. The influence of rate heterogeneity among sites on the time dependence of molecular rates. Molec. Biol. Evol. 2012, 29, 3345-3358.

30. Cai, D.; Sun, Y.; Tang, Z.; Hud, S.; Li, W.; Zhao, X.; Xiang, H.; Zhou, H. The origins of Chinese domestic cattle as revealed by ancient DNA analysis. J. Archaeol. Sci. 2014, 41, 423-434.

31. Mannen, H.; Kojima, T.; Oyama, K.; Mukai, F.; Ishida, T.; Tsuji, S. Effect of mitochondrial DNA variation on carcass traits of Japanese Black cattle. J. Anim. Sci. 1998, 76, 36-41.

32. Kantanen, J.; Edwards, C.J.; Bradley, D.G.; Viinalass, H.; Thessler, S.; Ivanova, Z.; Kiselyova, T.; Cinkulov, M.; Popov, R.; Stojanovic, S.; et al. Maternal and paternal genealogy of Eurasian taurine cattle (Bos taurus). Heredity 2009, 103, 404-415.

33. Magee, D.A.; Meghen, C.; Harrison, S.; Troy, C.S.; Cymbron, T.; Gaillard, C.; Morrow, A.; Maillard, J.C.; Bradley, D.G. A partial African ancestry for the Creole cattle population of the Carribean. J. Hered. 2002, 93, 429-432.

34. Borges Lopes, M.A.; Marquez de Rezende, E.M. ABCZ História e Histórias; Câmara Brasileira do Livro: Sao Paulo, Brazil, 2001. (In Portuguese)

35. Magee, D.A.; Mannen, H.; Bradley, D.G. Duality in Bos indicus mtDNA diversity: support for geographical complexity in zebu domestication. In The Evolution and History of Human Populations in South Asia; Petraglia, M.D., Allchin, B., Eds.; Springer: New York, NY, USA, 2007; pp. 385-391.

36. Gou, X.; Wang, Y.; Yang, S.; Deng, W.; Mao, H. Genetic diversity and origin of Gayal and cattle in Yunnan revealed by mtDNA control region and SRY gene sequence variation. J. Anim. Breeding Genet. 2010, 127, 154-160.

37. Mohamad, K.; Olsson, M.; van Tol, H.T.; Mikko, S.; Vlamings, B.H.; Andersson, G.; Rodriguez-Martinez, H.; Purwantara, B.; Paling, R.W.; Colenbrander, B.; et al. On the origin of Indonesian cattle. PLoS One 2009, 4, e5490. 
38. Takeda, K.; Satoh, M.; Neopane, S.P.; Kuwar, B.S.; Joshi, H.D.; Shrestha, N.P.; Fujise, H.; Tasai, M.; Tagami, T.; Hanada, H. Mitochondrial DNA analysis of Nepalese domestic dwarf cattle Lulu. Anim. Science J. 2003, 75, 103-110.

39. Shi, J.; Qiao, H.; Hosoi, E.; Ozawa, S. Phylogenetic relationship between the Yellow cattle in Qinghai province, China, and Japanese Black cattle based on mitochondrial DNA D-loop sequence polymorphism. GenBank 2004, AB177788-AB177796.

40. Yue, X.P.; Li, R.; Xie, W.M.; Xu, P.; Chang, T.C.; Liu, L.; Cheng, F.; Zhang, R.F.; Lan, X.Y.; Chen, H.; et al. Phylogeography and domestication of Chinese swamp buffalo. PLoS One 2013, 8, e56552.

41. Soares, P.; Abrantes, D.; Rito, T.; Thomson, N.; Radivojac, P.; Li, B.; Macaulay, V.; Samuels, D.C.; Pereira, L. Evaluating purifying selection in the mitochondrial DNA of various mammalian species. PLoS One 2013, 8, e58993.

42. Wang, Z.; Yonezawa, T.; Liu, B.; Ma, T.; Shen, X.; Su, J.; Guo, S.; Hasegawa, M.; Liu, J. Domestication relaxed selective constraints on the yak mitochondrial genome. Molec. Biol. Evol. 2011, 28, 1553-1556.

43. Paneto, J.C.; Ferraz, J.B.; Balieiro, J.C.; Bittar, J.F.; Ferreira, M.B.; Leite, M.B.; Merighe, G.K.; Meirelles, F.V. Bos indicus or Bos taurus mitochondrial DNA-Comparison of productive and reproductive breeding values in a Guzerat dairy herd. Genet. Molec. Res. 2008, 7, 592-602.

44. Horsburgh, K.A.; Prost, S.; Gosling, A.; Stanton, J.A.; Rand, C.; Matisoo-Smith, E.A. The genetic diversity of the Nguni breed of African cattle (Bos spp.): Complete mitochondrial genomes of haplogroup T1. PLoS One 2013, 8, e71956.

(C) 2014 by the authors; licensee MDPI, Basel, Switzerland. This article is an open access article distributed under the terms and conditions of the Creative Commons Attribution license (http://creativecommons.org/licenses/by/3.0/). 